\title{
Analisis Pendapatan dan Optimalisasi Input Peternak Sapi Potong Rakyat Binaan Sarjana Membangun Desa Wirausahawan Pendamping (Smdwp) yang Berkelanjutan di Kabupaten Tasikmalaya
}

\author{
Income Analysis and Input Optimization of Sustainable Beef Cattle Farming Sarjana Membangun \\ Desa Wirausahawan Pendamping/SMDWP Assisted in Tasikmalaya District
}

\author{
K. Sukmayadi ${ }^{1}$, A. Ismail ${ }^{2}$, A Hidayat ${ }^{2}$ \\ ${ }^{1}$ Mahasiswa Jurusan Ekonomi Sumberdaya dan Lingkungan, FEM IPB \\ ${ }^{2}$ Dosen Jurusan Ekonomi Sumberdaya dan Lingkungan, FEM IPB \\ Departemen Ekonomi dan Sumberdaya Lingkungan FEM IPB \\ Email : kusnas@yahoo.co.id 082218150030
}

\begin{abstract}
This research aims to estimate income, return-cost ratio ( $\mathrm{R} / \mathrm{C}$ ratio) and input optimization of Sarjana Membangun Desa Wirausahawan Pendamping (SMDWP) assited beef cattle farmers in Tasikmalaya District with different business systems, mainly to observe internalization of externalities by integrating waste management system into their business system. Data collection was conducted in September and October 2016 at SMDWP asissited beef cattle farmers groups in Tasikmalaya District. Quantitative reseach, in which the data were analyzed with statistical analysis by calculating the average income, $\mathrm{R} / \mathrm{C}$ ratio and Cobb Douglass regression function to observe input optimization. Data collection conducted by census. The results of this research suggest that the highest income estimation and $R / C$ ratio was beef cattle fattening farmers with integrated waste management system which cattle ownership is above $5 \mathrm{AU}$ more, which is $\mathbf{R p . 1 0 . 2 7 5 . 0 0 0 / m o n t h}$ and 2,301 respectively. The lowest income estimation and $R / C$ ratio was beef cattle breeding farmers without integrated waste management system which cattle ownership between 3-4 AU, which is Rp.454.127/month and 1,125 respectively. Factors that technically affect the production function was the amount of forages, amount of concentrate feeds, initial cattle weight, cattle breeds. Input application in the beef cattle farming at SMDWP fostered beef cattle farmers groups in Tasikmalaya District are not optimized, which is the amount of forages, amount of concentrate feeds, and initial cattle weight.
\end{abstract}

Keywords: $\mathrm{R} / \mathrm{C}$ ratio, zero waste, internalization of externalities

\section{PENDAHULUAN}

Jaminan ketersediaan pangan menjadi objek perhatian pemerintah dalam menjaga stabilitas keamanan pangan nasional. Konsumsi domestik yang meningkat tiap tahun akibat bertambahnya jumlah penduduk dan daya beli masyarakat mengharuskan pemerintah lebih fokus pada pembangunan ketahanan pangan berlandaskan pada pemberdayaan potensi lokal yang berkelanjutan. Sektor peternakan mempunyai peranan yang sangat penting dalam pembangunan nasional khususnya ketersediaan pangan nasional, karena permintaan protein hewani akan terus meningkat seiring dengan bertambahnya jumlah penduduk dan daya beli masyarakat tersebut. Dalam rangka pemenuhan kebutuhan protein hewani, maka salah satu usaha yang dilakukan adalah pengembangan usaha ternak sapi potong.

Tulang punggung industri sapi potong nasional bertumpu pada peternakan rakyat yang tersebar di seluruh Indonesia. Kelangkaan daging sapi yang terjadi membuat pemerintah pun memasukan daging sapi beku impor ke dalam pasar sebagai bentuk usaha menetralisir perubahan harga yang melambung tinggi, namun langkah tersebut belum dapat mengatasi permasalahan yang terjadi (Ilham 2009). Kondisi kelangkaan daging sapi ini menyebabkan terjadinnya fenomena tragedy of the commonds seperti pada tahun 2015 terutama menjelang hari besar keagamaan seperti Hari Raya Idul Fitri. Peternakan rakyat merupakan suatu bidang yang memiliki potensi untuk dikembangkan, namun dalam usaha mengembangkan salah satu subsektor pertanian ini perlu adanya saling kerjasama di antara berbagai pihak atau stakeholder, selain itu perlu juga membentuk sumber daya manusia yang tangguh, sehingga masyarakat dapat memiliki mindset dalam pengembangan perekonomian mereka secara sustainable, yakni dengan mengembangkan kelompok tani yang ada di pedesaan dalam rangka mengakomodir usaha masyarakat pedesaan.

Usaha peternakan dalam negeri dihadapkan pada perkembangan lingkungan strategik yang sangat dinamis. Berkaitan dengan hal tersebut diatas, pada tahun 
2014 Direktorat Jenderal Peternakan dan Kesehatan Hewan memfasilitasi tenaga terdidik lulusan perguruan tinggi bidang peternakan dan kesehatan hewan melalui program Sarjana Membangun Desa Wirausahawan Pendamping (SMDWP) untuk ditempatkan di pedesaan guna memberikan pendampingan teknis dan manajerial kepada kelompok tani ternak. Kehadiran SMDWP di kelompok tani ternak yang berbekal ilmu dan teknologi, kreativitas serta wawasan agribisnis, diharapkan dapat memberikan solusi dan membantu petani peternak dalam meningkatkan kinerja dan performance kelompok dalam meningkatkan produktifitas dan efisiensi usaha serta mampu meningkatkan daya saing (Dirjenak 2014).

Kabupaten Tasikmalaya merupakan salah satu kabupaten di Wilayah Priangan Timur Provinsi Jawa Barat yang mempunyai potensi pengembangan peternakan sapi potong rakyat yang berbasis kelompok, hal ini ditunjukan dengan populasi sapi potong pada tahun 2014 sebanyak 47.427 ekor dan tahun sebelumnya sebanyak 51.861 ekor. Di Kabupaten Tasikmalaya terdapat 1.946 Kelompok Tani yang bergabung pada 326 Gapoktan, dengan 240 kelompok tani peternak sapi potong, (Kab. Tasikmalaya Dalam Angka 2015). Program SMDWP di Kabupaten Tasikmalaya saat ini diikuti oleh 2 orang SMDWP, dengan jumlah kelompok binaan lebih dari 12 kelompok dan sebagian besarnya adalah kelompok ternak sapi potong rakyat. Arah pengembangan usaha ternak sapi potong yang dibina SMDWP Kabupaten Tasikmalaya beragam dari mulai pembibitan yang belum terintegrasi dengan pengolahan limbah sampai ke pengembangan kelompok ternak sapi potong rakyat penggemukan yang sudah terintegrasi dengan pengolahan limbahnya (internalisasi eksternalitas), tujuan utama pendampingan ini adalah meningkatkan pendapatan peternak sapi potong rakyat, dengan memberi bimbingan teknis budidaya agar terciptanya usaha ternak sapi potong yang optimal dan efisien. Namun pada kenyataannya para peternak binaan ini belum sepenuhnya mengintroduksi teknologi dari hasil bimbingan para SMDWP tersebut, sehingga harus dilihat optimalisasi input dan pendapatan dari berbagai pola usaha ternak sapi potong rakyat berbasis kelompok binaan SMDWP di Kabupaten Tasikmalaya ini.

Penelitian ini bertujuan mengestimasi pendapatan, $\mathrm{R} / \mathrm{C}$ rasio dan optimalisasi input peternak sapi potong rakyat binaan SMDWP di Kabupaten Tasikmalaya serta impilkasi kebijakan agar usaha ternak sapi potong rakyat menuju pengembangan yang berkelanjutan.

\section{MATERI DAN METODE}

\section{Waktu dan Tempat}

Lokasi penelitian ini adalah para peternak anggota kelompok-kelompok binaan Sarjana Membangun Desa Wirausahawan Pendamping (SMDWP) di Kabupaten Tasikmalaya, yang tersebar di Kecamatan Kadipaten, Pageurageung, Manonjaya, Gunung Tanjung, Jatiwaras dan Sukaraja. Pemilihan lokasi penelitian dilakukan secara sengaja (purposive). Pertimbangan penentuan lokasi penelitian adalah karena pada lokasi tersebut terdapat kelompok-kelompok peternak sapi potong binaan
SMDWP dengan keberagaman pola, arah serta startegi dalam pengembangan usaha ternak sapi potongnya, yang berdampak pada keragaman pendapatan para peternak sapi potong rakyat di daerah tersebut. Penelitian ini dilaksanakan pada bulan September dan Oktober 2016

Teknik Penentuan Responden

Teknik Penentuan responden dilakukan dengan Sensus, yaitu seluruh populasi dijadikan sampel. Sehingga jumlah sampelnya adalah berjumlah 77 orang peternak yang meruapakan seluruh peternak binaan SMDWP Kabupaten Tasikmalaya Provinsi Jawa Barat.

\section{Variabel Penelitian}

Variabel-variabel analisis pendapatan dan analisa fungsi produksi pada penelitian ini dapat dilihat pada Tabel 1. Pada penghitngan pendapatan dibedakan berdasarkan arah pengembangan usaha yang terdapat dilokasi penelitian dimana ada 4 pola pengembangan berdasarkan karakter usaha ternakna yaitu sebagai pembibitan atau sebagai penggemukan, selain itu pola ini dibedakan berdasarkan integrasi usaha ternaknya dengan pengolahan limbah, sehingga arah pengembangan usaha ternak sapi potong di lokasi penelitian yaitu :

1. Pembibitan Tanpa Pengolahan Limbah

2. Pembibitan Dengan Pengolahan Limbah

3. Penggemukan Dengan Pengolahan Limbah

4. Penggemukan Tanpa Pengolahan Limbah

\section{Metode Analisis}

Pendapatan peternak adalah hasil pengurangan total penerimaan dengan jumlah biaya yang dikeluarkan oleh peternak dalam satu kali periode, dan dikonversikan ke nilai pendapatan dalam satu bulan dengan satuan rupiah. Untuk menghitung pendapatan peternak digunakan rumus:

$\pi=T R-T C$ (Soekartawi 1995)

Keterangan:

$\Pi=$ Pendapatan petani

$\mathrm{TR}=$ Total penerimaan

$\mathrm{TC}=$ Total biaya produksi

Menurut Mubyarto (1989), efisiensi usaha ternak merupakan hasil bersih (netto) dari kegiatan usaha ternak yang diperoleh setelah mengurangkan hasil atau pendapatan kotor (bruto) dari produksi dengan jumlah seluruh biaya produksi yang dikeluarkan oleh peternak. Apabila hasil usahaternak tersebut besar, maka ini mencerminkan rasio yang baik dari nilai hasil dan biaya. Semakin tinggi rasio berarti usahaternak tersebut semakin efisien. Efisiensi ekonomi suatu usaha ternak dapat dilakukan dengan pendekatan fungsi keuntungan. Tingkat efisiensi usaha ternak dapat diketahui melalui analisis $\mathrm{R} / \mathrm{C}$ rasio. $\mathrm{R} / \mathrm{C}$ rasio merupakan rasio penerimaan dan biaya. Analisis $\mathrm{R} / \mathrm{C}$ rasio dalam usaha ternak biasanya menggambarkan tingkat efisiensi usaha ternak berdasarkan rasio antar variabel biaya yang harus dikeluarkan dan penerimaan yang diterima.

Analisis Optimalisasi input digunakan regresi fungsi produksi yang mengacu model pada penelitian Arfa'i (1992). Dalam melakukan pendugaan digunakan model log natural yaitu ; 
Tabel 1 Variabel penelitian pendapatan peternak sapi potong rakyat binaan SMDWP di Kabupaten Tasikmalaya

\begin{tabular}{|c|c|c|}
\hline Variabel & Sub Variabel & Indikator Pengukuran \\
\hline \multirow[t]{12}{*}{ Pendapatan } & Total Penerimaan (TR) & 1. Nilai sapi yang jadi stock dan dijual, Pedet, Afkir, Bakalan (Rp,-) \\
\hline & & 2. Nilai hasil olahan limbah $(\mathrm{Rp},-)$ \\
\hline & & Pupuk organik padat,Pupuk cair,Biogas \\
\hline & Total Biaya (TC) & 1. Biaya Tetap $(\mathrm{Rp},-)$ \\
\hline & & Biaya penyusutan kandang, \\
\hline & & Biaya penyusutan peralatan, \\
\hline & & Biaya penyusutan peralatan pengolahan limbah, Biaya Lain2 \\
\hline & & 2. Biaya Variabel $(\mathrm{Rp},-)$ \\
\hline & & Biaya hijauan makanan ternak, \\
\hline & & $\begin{array}{l}\text { Biaya konsentrat, Tenaga kerja luar keluarga, Keswan dan IB, Biaya pen- } \\
\text { golahan limbah }\end{array}$ \\
\hline & & 3. Biaya Non Tunai $(\mathrm{Rp},-)$ \\
\hline & & Biaya tenaga kerja keluarga, Biaya sewa lahan \\
\hline \multirow[t]{4}{*}{ Fungsi Produksi } & - Jumlah Pemberian HMT & Jumlah Pemberian HMT Selama Pemeliharaan $(\mathrm{Kg})$ \\
\hline & - Jumlah Pemberian Konsentrat & Jumlah Pemberian Konsentrat Selama Pemeliharaan $(\mathrm{Kg})$ \\
\hline & - Bobot Awal Pemeliharaan & Berat Bobot Awal Pemeliharaan $(\mathrm{Kg})$ \\
\hline & - Bangsa Sapi & $\begin{array}{l}\text { Bangsa Sapi (dummy), } 1=\mathrm{PO}, 0=\text { Selain PO ( } \mathrm{PO} \text { dijadikan dasar kerena } \\
\text { hamper } 70 \% \text { populasi di lokasi penelitian adalah bangsa sapi PO) }\end{array}$ \\
\hline
\end{tabular}

$\operatorname{Ln} Y_{i}=\operatorname{Ln} \beta_{0}+\beta_{1} \operatorname{Ln} X_{1}+\beta_{2} \operatorname{Ln} X_{2}+\beta_{3} \operatorname{Ln} X_{3}+\operatorname{Ln} D_{i} \varepsilon$

Keterangan :

$\mathrm{Y}_{\mathrm{i}}=$ Pertambahan bobot badan selama pemeliharaan $(\mathrm{Kg})$

$\mathrm{X}_{1 \mathrm{i}}=$ Jumlah konsentrat yang diberikan selama pemeliharaan $(\mathrm{Kg})$

$\mathrm{X}_{2 \mathrm{i}}=$ Jumlah hijauan yang diberikan selama pemeliharaan ( $\mathrm{Kg})$

$\mathrm{X}_{3 \mathrm{i}}=$ Bobot awal pemeliharaan $(\mathrm{Kg})$

Variabel Dummy= bangsa Sapi

$\beta_{0}=$ Intersep

$\beta_{1}, \beta_{2}, \beta_{3}, \beta_{4}, \beta_{5}, \beta_{6}=$ Koefisien regresi

$\varepsilon=$ Error $/$ Galat

Pengujian fungsi produksi dilakukan untuk mengevaluasi apakah model yang digunakan sudah baik atau tidak. Pengujian model secara statistik antara lain terdiri dari koefisien determinasi, uji-t, dan uji-F serta uji statistic klasik lainnya (Juanda B 2009)

Penentuan penggunaan input optimal untuk setiap input adalah :

Jika $\frac{N P M_{i}}{v_{i}}=1$, atau $\frac{N P M}{B K M}=1$, maka usaha tersebut efisien.

Jika $\frac{N P M}{B K M}<1$, usaha tersebut tidak efisien, harus mengurangi
jumlah input

Jika $\frac{N P M}{B K M}>1$, maka usaha tersebut tidak efisien, harus
menambah jumlah input

Keterangan :

NPM = Nilai Produk Marjinal

$\mathrm{BKM}=$ Biaya Korbanan Marginal $\left(v_{i}\right)$

\section{HASIL DAN PEMBAHASAN}

\section{Analisis Pendapatan}

Dalam penelitian ini menggunakan dua macam biaya, adapun jenis dan besarnya biaya produksi dari peternak sapi potong rakyat binaan SMDWP di Kabupaten Tasikmalaya sesuai dengan (Rahardja 2000). Biaya produksi adalah nilai fisik penggunaan faktor produksi yang diukur dengan uang. Komponen biaya produksi usahaternak adalah biaya tetap dan biaya variabel. Penerimaan usahaternak sapi potong yang paling utama adalah dari penjualan sapi bakalan.

\section{Biaya Tetap}

Biaya tetap peternak sapi potong rakyat binaan SMDWP di Kabupaten Tasikmalaya merupakan biaya yang jumlahnya tidak mengalami perubahan meskipun terjadi peningkatan atau penurunan jumlah produksi, atau dengan kata lain biaya ini tidak dipengaruhi oleh banyak jumlah sapi yang dipelihara. biaya tetap adalah biaya yang tidak berubah (konstan) untuk setiap tingkatan/sejumlah hasil yang diproduksi. Adapun komponen biaya tetap peternak sapi potong rakyat binaan SMDWP di Kabupaten Tasikmalaya meliputi biaya penyusutan kandang, biaya penyusutan peralatan, biaya penyusutan peralatan pengolah limbah bagi responden yang sudah melakukan pengolahan limbah.

\section{Biaya Variabel}

Biaya variabel adalah biaya yang berubahubah akibat dari perubahan jumlah produksi. Artinya besar kecilnya biaya ini sangat dipengaruhi oleh jumlah produksi ternak sapi potong setiap tahunnya. Hal tersebut sesuai dengan pendapat Swastha dan Sukotjo (1993) yang menyatakan bahwa biaya variabel adalah biaya yang berubah disebabkan oleh adanya perubahan jumlah hasil. Biaya 
Tabel 2 Total Biaya per Bulan

\begin{tabular}{|c|c|c|c|}
\hline Arah Pengembangan & $\begin{array}{l}\text { Jumlah Kepemilikan Ternak } \\
\text { (ST) }\end{array}$ & $\begin{array}{l}\text { Jumlah Responden } \\
\text { (orang) }\end{array}$ & $\begin{array}{c}\text { Total Biaya per Bulan } \\
(\mathrm{Rp},-)\end{array}$ \\
\hline \multirow[t]{3}{*}{ Pembibitan tanpa pengolahan limbah } & $1-2$ & 10 & $1.884 .688,-$ \\
\hline & $3-4$ & 1 & $3.631 .875,-$ \\
\hline & $\geq 5$ & 0 & 0 \\
\hline \multirow[t]{3}{*}{ Pembibitan dengan pengolahan limbah } & $1-2$ & 14 & 2.128.333,- \\
\hline & $3-4$ & 10 & 3.898.021,- \\
\hline & $\geq 5$ & 1 & $5.911 .548,-$ \\
\hline \multirow[t]{3}{*}{ Penggemukan dengan pengolahan limbah } & $1-2$ & 9 & $1.958 .438,-$ \\
\hline & $3-4$ & 21 & $4.282 .188,-$ \\
\hline & $\geq 5$ & 1 & $5.925 .000,-$ \\
\hline \multirow[t]{3}{*}{ Penggemukan tanpa pengolahan limbah } & $1-2$ & 7 & 2.093.750,- \\
\hline & $3-4$ & 3 & $3.671 .875,-$ \\
\hline & $\geq 5$ & 0 & 0 \\
\hline Jumlah Responden & & 77 & \\
\hline
\end{tabular}

Sumber : Data primer yang telah diolah

Tabel 3 Penerimaan Peternak Sapi Potong Rakyat Binaan SMDWP di Kabupaten Tasikmalaya

\begin{tabular}{|c|c|c|c|}
\hline Arah Pengembangan & $\begin{array}{l}\text { Jumlah Kepemilikan Ternak } \\
\text { (ST) }\end{array}$ & $\begin{array}{l}\text { Jumlah Responden } \\
\text { (orang) }\end{array}$ & $\begin{array}{c}\text { Penerimaan per Bulan } \\
(\mathrm{Rp},-)\end{array}$ \\
\hline \multirow[t]{3}{*}{ Pembibitan tanpa pengolahan limbah } & $1-2$ & 10 & $2.043 .000,-$ \\
\hline & $3-4$ & 1 & $4.086 .000,-$ \\
\hline & $\geq 5$ & 0 & 0 \\
\hline \multirow[t]{3}{*}{ Pembibitan dengan pengolahan limbah } & $1-2$ & 14 & $3.946 .500,-$ \\
\hline & $3-4$ & 10 & $6.906 .375,-$ \\
\hline & $\geq 5$ & 1 & $9.855 .000,-$ \\
\hline \multirow[t]{3}{*}{ Penggemukan dengan pengolahan limbah } & $1-2$ & 9 & $4.089 .375,-$ \\
\hline & $3-4$ & 21 & $9.591 .875,-$ \\
\hline & $\geq 5$ & 1 & 13.631.250,- \\
\hline \multirow[t]{3}{*}{ Penggemukan tanpa pengolahan limbah } & $1-2$ & 7 & $4.230 .000,-$ \\
\hline & $3-4$ & 3 & $6.345 .000,-$ \\
\hline & $\geq 5$ & 0 & 0 \\
\hline Jumlah Responden & & 77 & \\
\hline
\end{tabular}

Sumber : Data Primer yang telah diolah

variabel pada peternak sapi potong rakyat binaan SMDWP di Kabupaten Tasikmalaya meliputi biaya hijauan makanan ternak, biaya konsentrat, biaya tenaga kerja luar keluarga, biaya Inseminasi Buatan (IB) dan Kesehatan Hewan atau keswa (berupa vitamin, suplemen dan perawatan kesehatan dan obat-obatan), serta biaya pengolahan limbah.

\section{Total Biaya}

Total Biaya adalah penjumlahan seluruh biaya produksi, yaitu biaya tetap dan biaya vaiabel, besaran dari total biaya perpeternakyang menjadi responden berdasarakan pola pengembangan usaha dan jumlah kepemilikan ternak disajikan pada Tabel 2. Penerimaan yang diperoleh peternak selama satu periode terakhir dapat dihitung dari jumlah $\mathrm{Kg}$ ternak yang masih ada di kandang dan dijual, serta hasil dari pengolahan limbah baik pupuk ataupn hasil biogas. Harga pasar dari bobot hidup sapi di daerah tasikmalaya pada saat penelitian adalah $\mathrm{Rp} 47.000,-/ \mathrm{Kg}$, untuk pupuk harganya adalah $\mathrm{Rp} 500,-/ \mathrm{Kg}$ dan untuk biogas disetarakan dengan harga gas elfiji yaitu Rp 45.000,- per hasil produksi yang setaradengan $40 \mathrm{Kg}$ gas elfiji. Besarnya total penerimaan yang diperoleh peternak sapi potong rakyat binaan SMDWP di Kabupaten Tasikmalaya berdasarkan jumlah kepemilikan ternak dan pola pengembangan usahanya dapat dilihat pada Tabel 3.

Berdasarkan hasil yang diperoleh maka dapat ditarik kesimpulan bahwa pendapatan peternak usaha sapi potong rakyat binaan SMDWP di Kabupaten Tasikmalaya Provinsi Jawa Barat memberikan gambaran yang bervariasi, karena terestimasi keuntungan yang signifikan bagi peternak yang pola pengembangan penggemukan dan pembibitan, selain itu peningkatan keuntungan yang signifikan juga diperoleh oleh peternak yang sudah mengintegrasikan usahanya dengan pengolahan limbah. Pengolahan limbah, bukan hanya secara finansial saja dapat memberikan manfaat, 
tetapi jika lebih jauh dihitung akan memberikan berbagai manfaat baik secara sosial dan ekologi atau lingkungan.

Hasil penelitian juga menunjukan bahwa arah pengembangan pembibitan yang terintegrasi dengan pengolahan adalah arah pengembangan yang terbaik untuk dilakukan pada usaha ternak sapi potong rakyat. Rata-rata keuntungan dan $\mathrm{R} / \mathrm{C}$ rasio per bulan dapat dilihat pada Tabel 4.

Dari hasil penghitungan pendapatan ini sangat terlihat jelas manfaat secara finansial dari proses pengolahan limbah, manfaat lainnya yaitu berkurangnya ekternalitas negatif dari usaha ternak sapi potong rakyat terhadap lingkungan.

Biogas hasil pengolahan limbah ternak sapi potong mempunyai keunggulan terhadap lingkungan dibandingkan dengan Bahan Bakar Minyak (BBM) yang berasal dari fosil, yaitu sifatnya yang ramah lingkungan dan dapat dipebaharui. Keunggulan lainnya, limbah dari hasil proses instalasi biogas tidak menimbulkan bau menyengat. Ampas atau slunge yang didapat dari proses pembuatan biogas, bisa diproses kembali menjadi pupuk organik. Dengan pengolahan ini dapat mengurangi limbah yang dibuang ke sungai sehingga tingkat pencemaran sungai akibat limbah dari peternakan dapat dikurangi.

Apabila melihat potensi dari hasil samping biogas tersebut maka terdapat peluang pengembangan usaha untuk memproduksi pupuk organik. Karena saat ini pupuk organik sangat dibutuhkan petani untuk mengembalikan kesuburan tanah lahan mereka yang kritis, Disamping itu bahan bakunya pun mudah didapatkan oleh petani sekitar usaha peternakan sapi potong rakyat ini.

Hasil perhitungan pendapatan dan $\mathrm{R} / \mathrm{C}$ rasio pada penelitian ini jika dibandingkan dengan pendapatan dan $\mathrm{R} / \mathrm{C}$ rasio dari data sekunder yang diperoleh, maka nilainya lebih tinggi yaitu pendapatan dan $\mathrm{R} / \mathrm{C}$ rasio $\mathrm{Rp}$ 7.012.917 dengan $\mathrm{R} / \mathrm{C}$ rasion 2,241. Sedangkan data sekunder dari hasil penelitian terdahulu yaitu menurut Noryadi (2014) perhitungan pendapatan dan $\mathrm{R} / \mathrm{C}$ rasio untuk usaha ternak sapi potong rakyat di Jawa Barat sebesar Rp 818.135 dengan $\mathrm{R} / \mathrm{C}$ nya sebesar 1,40 . Hal ini dapat menunjukan bahwa dengan adanya pendampingan dari SMDWP dan usahanya sudah terintegrasi dengan pengolahan limbah maka usaha ternak sapi potong rakyat lebih menguntungkan.

\section{Optimalisasi Input}

Indikator keberhasilan dari usaha ternak dapat dilihat dari tingkat efisiensinya. Tingkat efisiensi ini dapat tergambar dari pengunaan input optimal yang diguakan dari berbagai faktor produksi yang tergambar dari suatu fungsi produksi, alat analisis faktor-faktor produksi dalam penelitian ini adalah fungsi Cobb-Douglas dengan menggunakan peubah yang diamati berupa pertambahan bobot badan selama pemeliharaan sebagai peubah tidak bebas, sedangkan jumlah pemberian konsentrat selama pemeliharaan, jumlah pemberian hijauan selama pemeliharaan serta bobot awal pemeliharaan, dan bangsa sapi sebagai variabel dummy yang menjadi peubah bebas untuk analisa fungsi produksi. Hasil pengolahan data terhadap fungsi produksi diperoleh seperti pada Tabel 5 .

Nilai dari koefisien determinasi $\left(R^{2}\right)$ fungsi produksi adalah $86,2 \%$, berarti bahwa $86,2 \%$ variasi produksi (pertambahan bobit badan selama pemeliharaan) pada usaha penggemukan sapi potong rakyat di lokasi penelitian ini dapat dijelaskan oleh peubah-peubah jumlah pemberian konsentrat, hijauan, bobot awal penggemukan dan bangsa sapi potong yang dipelihara sebagai peubah dummy, sedangkan sisanya sebesar $13,8 \%$ tidak dapat diterangkan oleh model fungsi produksi yang digunakan dalam penelitian ini. Hal ini terjadi karena ada faktor produksi lain yang tidak diperhitungkan dalam fungsi produksi yang digunakan dalam penelitian ini seperti, tenaga kerja, penggunaan obat-obatan dan vitamin serta faktor lainnya.

Fungsi produksi pada penelitian ini secara matematis dapat di tulis :

$L N Y=-5,6757+1,12111 \operatorname{Ln} X_{1}+0,57754 \operatorname{Ln} X_{2}+0,00708$

Tabel 4 Keuntungan dan R/C Rasio per Bulan

\begin{tabular}{lcccc}
\hline Arah Pengembangan & $\begin{array}{c}\text { Jumlah Kepemilikan } \\
\text { Ternak (ST) }\end{array}$ & $\begin{array}{c}\text { Jumlah Responden } \\
\text { (orang) }\end{array}$ & $\begin{array}{c}\text { Keuntungan per } \\
\text { Bulan (Rp,-) }\end{array}$ & R/C Rasio \\
\hline Pembibitan tanpa pengolahan limbah & $1-2$ & 10 & $158.313,-$ & 1.059 \\
& $3-4$ & 1 & $454.125,-$ & 1.125 \\
Pembibitan dengan pengolahan limbah & $\geq 5$ & 0 & 0 & 0 \\
& $1-2$ & 14 & $1.818 .167,-$ & 1.854 \\
Penggemukan dengan pengolahan limbah & $3-4$ & 10 & $3.008 .354,-$ & 1.764 \\
& $1-2$ & 9 & $3.943 .542,-$ & 1.667 \\
Penggemukan tanpa pengolahan limbah & $3-4$ & 21 & $2.841 .250,-$ & 2,039 \\
& $\geq 5$ & 1 & $7.012 .917,-$ & 2.241 \\
Jumlah Responden & $1-2$ & 3 & $10.275 .000,-$ & 2.301 \\
\hline
\end{tabular}

Sumber : Data Primer yang telah diolah 
Table 5 Pengolahan Data Terhadap Fungsi Produksi Dalam Penelitian

\begin{tabular}{lllll}
\hline Peubah bebas & $\begin{array}{c}\text { Koefisien } \\
\text { Regresi }\end{array}$ & $\begin{array}{c}\text { Strandar } \\
\text { Error }\end{array}$ & t-hitung & Prob T \\
\hline Y & -56.757 & 0,7677 & $-7,39$ & 0,000 \\
& 112.111 & 0,04104 & 27,32 & 0,000 \\
& 0,57754 & 0,04119 & 14,02 & 0,000 \\
& 0,00708 & 0,09679 & 0,07 & 0,942 \\
Dummy & $-0,05860$ & 0,03007 & $-1,95$ & 0,053 \\
\hline
\end{tabular}

$\mathrm{R}-\mathrm{Sq}=86,9 \% ; \mathrm{R}-\mathrm{Sq}(\operatorname{adj})=86,4 \% ;$ Alfa $=5 \%$

$$
\operatorname{Ln} X_{3}-0,05860 \operatorname{LnD}
$$

Berdasarkan fungsi produksi diatas maka diperoleh persamaan fungsi produksi cobb douglasnya :

$$
Y=-5,6757 \mathrm{X}_{1}^{1,12111} \mathrm{X}_{2}^{0,57754} \mathrm{X}_{3}^{0,00708}
$$

Pada Tabel 6 dapat dilihat hasil perhitungan antara input aktual dan input optimal untuk usaha sapi potong rakyat peternak binaan SMDWP di Kabupaten Tasikmalaya. Nilai produk marjinal dari input pakan konsentrat adalah sebesar $6.617,81$ Kondisi ini berarti bahwa setiap penambahan satu kilogram pakan konsentrat akan meningkatkan pendapatan sebesar Rp 6.617,81 dengan biaya korbanan sebesar Rp 2.000/Kg. Tabel 6 juga menunjukkan nilai rasio NPM/BKM dari penggunaan input pakan konsentrat, yaitu sebesar 33,09 (NPM/BKM>1), ini berarti bahwa pemberian pakan konsentrat belum optimal, sehingga peternak responden perlu ditambah jumlah pemberian pakan konsentrat dari $160,559 \mathrm{Kg} / \mathrm{ST} /$ periode menjadi $180,3 \mathrm{Kg} / \mathrm{ST} /$ periode.

Nilai produk marjinal untuk input pakan HMT ialah sebesar 541,55 ini berarti bahwa setiap penambahan satu kilogram pakan HMT dapat meningkatkan pendapatan sebesar Rp 541,55 dengan biaya korbanan sebesar Rp 200 per kilogram. Rasio NPM/BKM dari penggunaan input pakan HMT ialah sebesar 27,08 (NPM/BKM>1). Kondisi ini berarti bahwa penggunaan input HMT oleh peternak responden belum optimal, sehingga peternak responden harus menambah penggunaan input pakan HMT dari 935,53 $\mathrm{Kg} / \mathrm{ST} /$ periode menjadi 954,1 Kg/ST/periode. Dimana periode penggemukan yaitu selama 120 hari.

Nilai produk marjinal dari penggunaan bobot badan awal ialah sebesar 276,3 sedangkan untuk nilai rasio NPM/BKM dari bobot badan awal ialah sebesar 0,00588 $(\mathrm{NPM} / \mathrm{BKM}>1)$. Kondisi ini berarti bahwa penggunaan input bobot awal oleh peternak responden belum optimal, sehingga peternak responden harus mengubah penggunaan bobot badan dari 224,7 Kg menjadi 218,4 Kg.

Pada optimalisasi input pertanian dikenal satu konsep yang disebut LEISA (Low external input sustainable agriculture), konsep ini merupakan penggabungan dua prinsip yaitu agro-ekologi serta pengetahuan dan praktek pertanian masyarakat setempat/tradisional berbasis lokal. Agro-ekologi merupakan studi holistik tentang ekosistim pertanian termasuk semua unsur lingkungan dan manusia. Dengan pendekatan LEISA diharapkan terjadinya usaha peternakan yang zero waste dan zero cost. Menurut Suharto (2007) Konsep LEISA secara singkat diuraikan sebagai berikut:

1. Mengoptimalkan pemanfaatan sumberdaya lokal, dalam hal ini pakan

2. Mengoptimalkan daur ulang (zero waste)

3. Meminimalkan kerusakan lingkungan

4. Mendiversikan usaha

5. Sasaran produksi stabil, memadai dalam jangka panjang

6. Menciptakan kemandirian

Strategi pengembangan usaha peternakan sapi dapat dilakukan melalui integrasi industri pengolahan bahan pakan dan usaha ternak dengan memperhatikan ketersediaan sumber daya ternak dan bahan baku lokal setempat. Hal ini dapat dilakukan antara lain dengan memperhatikan:

1. Pakan sumber serat harus dapat disediakan oleh peternak sendiri

2. Pakan tambahan (konsentrat) disusun berdasarkan perhitungan biaya untuk menghasilkan bobot badan tertentu

3. Meminimalkan penggunaan bahan bahan impor.

Pemberdayaan masyarakat perlu dilakukan karena peningkatan produksi sapi nasional harus searah dengan perbaikan taraf hidup masyarakat untuk dapat hidup lebih sejahtera. Pembentukan kelompok peternak dan gabungan kelompok peternak berdasarkan prinsip-prinsip berkooperasi yang baik perlu terus dilaksanakan. Hal ini sangat penting dalam meningkatkan peran kelompok peternak dalam posisi tawar, akses informasi dan efektivitas komunikasi yang pada umumnya masih sangat rendah. Upaya ini harus juga disertai dengan pemberian fasilitas kemudahan akses petani pada lembaga keuangan mikro melalui berbagai skim pembiayaan pertanian, serta pendampingan secara efektif dan konsisten.

\section{Implikasi Kebijakan}

Berdasarkan hasil analisis diatas, maka dirumuskan beberapa implikasi kebijakan dalam pengembangan sapi potong rakyat berbasis kelompok binaan SMDWP di Kabupaten Tasikmalaya yang berkelanjutan. Adapun implikasi kebijakan yang diambil meliputi 3 pilar pembangunan berkelanjutan yaitu aspek ekonomi, sosial,

Tabel 6 Rasio NPM Dan BKM Usahaternak Milik Peternak Responden

\begin{tabular}{lcccccc}
\hline Faktor produksi & Koefisien regresi & Input aktual & NPM & BKM & Rasio NPM/BKM & Input Optimal \\
\hline Konsentrat & 1,211 & 160.559 & 6617,81 & 2000 & 33,09 & 180,3 \\
HMT & 0,57754 & 935,53 & 541,55 & 200 & 27,08 & 954,1 \\
Bobot awal & 0,00708 & 224,7 & 276,3 & 47000 & 0,00588 & 218,4 \\
\hline
\end{tabular}

Sumber : Data primer yang telah diolah 
dan lingkungan.

\section{A. Aspek Ekonomi}

Kebijakan aspek ekonomi ini diambil menyangkut pengembangan harga dan pasar. Adapun kebijakannnya adalah sebagai berikut:

1. Peningkatan skala usaha ternak.

2. Pengembangan pakan bahan konsentrat murah dan berkualitas dengan bahan dasar yang berasal dari lokal.

\section{B. Aspek Sosial}

Kebijakan aspek sosial ini ditujukan untuk pengembangan sumberdaya peternak, agar memiliki kemampuan beternak yang baik. Adapun kebijakan aspek sosial meliputi:

1. Peningkatan tenaga pendamping baik secara kualitas dan kuantitasnya dengan peningkatan kompetensi melalui berbagai pelatihan.

2. Pembentukan kelompok peternak dan gabungan kelompok peternak berdasarkan prinsip-prinsip berkooperasi yang baik, dengan penguatan lembaga pemasaran, dan rantai tataniaga.

\section{Aspek Lingkungan}

Kebijakan dari aspek lingkungan dilakukan agar peternakan sapi potong memiliki kepedulian terhadap lingkungan hidup. Adapun kebijakan aspek lingkungan adalah sebagai berikut:

1. Pengembangan budidaya rumput untuk pakan.

2. Peningkatan sistem integrasi usaha tani antara tanaman dengan ternak.

3. Pengembangan pemanfaatan limbah ternak.

\section{KESIMPULAN}

Pendapatan usaha ternak sapi potong rakyat peternak binaan SMDWP di Kabupaten Tasikmalaya sangat bervariasi, terutama terdapat perbedaan signifikan antara peternak dengan pola penggemukan dan pola pembibitan, selain itu peternak yang sudah mengintegrasikan usahanya dengan pengolahan limbah dan yang belum terintegrasi dengan pengolahan limbahnya. Pengolahan limbah merupakan usaha untuk meningkatkan pendapatan selain berdampak positif pada lingkungan, yaitu mengurangi eksternalitas negatif dari usaha ternak sapi potong. Penggunaan input produksi dalam usaha sapi potong rakyat kelompok peternak binaan SMDWP di Kabupaten Tasikmalaya belum optimal, seperti jumlah pemberian HMT, jumlah pemberian konsentrat dan bobot awal pemeliharaan. Konsep LEISA merupakan suatu strategi untuk mencapai pengembangan usaha ternak sapi potong rakyat yang berkelanjutan.

\section{DAFTAR PUSTAKA}

Arfa'i. 1992. Analisis Fungsi Produksi dan Biaya Produksi Perusahaan Peternakan Sapi Potong di Kecamatan Cicurug Kabupaten Sukabumi. Tesis. Program Pascasarjana, Institut Pertanian Bogor, Bogor.

BPS Kabupaten Tasikmalaya. 2015. Kabupaten
Tasikmalaya Dalam Angka 2015

Direktorat Jenderal Peternakan Dan Kesehatan Hewan Kementrian Pertanian Republik Indonesia. 2014. Laporan Kinerja Tahun 2014. Jakarta

Debertin DL. 1986. Agricultural Production Economics. Macmillan Publishing Company. New York

Hernanto F. 1989. Ilmu Usahatani. Jakarta (Id): Penebar Swadaya.

Ilham N. 2009. Kelangkaan produksi daging: Indikasi dan Implemtasi, Bogor (ID): Pusat Analisis Sosial Ekonomi dan Kebijakan Pertanian. J Analisis Kebijakan Pertanian. 7(1):43-63-198.

Juanda B. 2009. Ekonometrika: Pemodelan dan Pendugaan. Bogor(Id):IPB Press.

Mubyarto. 1989. Pengantar Ekonomi Pertanian. Edisi Keempat. Jakarta(Id): LP3ES.

Noryadi. 2014. Analisis Ekonomi Pengembangan Usaha Ternak Sapi Potong Di Kabupaten Garut. Tesis. Sekolah Pascasarjana Institut Pertanian Bogor. Bogor

Soekartawi. 1995. Analsis Usahatani. Jakarta (Id): Universitas Indonesia (UI-Press).

Suharto. 2007. Peternakan Sapi Perah dengan Pendekatan Zero Waste dan Zero Cost. Makalah disampaikan pada Panel Diskusi Pemberdayaan Masyarakat melalui Model Pengembangan Sapi Potong. Puslitbang Peternakan bekerjasama dengan Ditjen Peternakan, Jakarta. 